Elsevier

MTR 08631

\title{
Metallothionein protein variants generated in rat liver as a result of DNA and RNA ethylations by the carcinogen diethylnitrosamine
}

\author{
A. Jauch * and W.K. Lutz ** \\ Institute of Toxicology, ETH and University of Zurich, CH-8603 Schwerzenbach (Switzerland)
}

(Received 18 March 1986)

(Revision received 3 June 1986)

(Accepted 9 June 1986)

\section{Summary}

Metallothionein (MT) is a protein which contains 20 cysteine residues but no aromatic amino acids. It was tested whether treatment of male rats with the hepatocarcinogen diethylnitrosamine (DENA) could ethylate nucleic acids in such a way that protein variants containing measurable amounts of aromatic amino acid residues could be isolated from the livers of treated animals. To give a low limit of detection, the "wrong" amino acid precursors were administered in radiolabelled form at high levels of activity (7 $\mathrm{mCi} / \mathrm{kg}$ each of $\left[{ }^{3} \mathrm{H}\right]$ tyrosine and $\left[{ }^{3} \mathrm{H}\right]$ phenylalanine). $11 \mu \mathrm{Ci} / \mathrm{kg}\left[{ }^{14} \mathrm{C}\right]$ cysteine was given as an internal marker for MT biosynthesis. $6 \mathrm{~h}$ after amino acid administration, metallothionein (MT) was isolated from the liver and extensively purified. After acid hydrolysis and collection of Cys, Tyr, and Phe from an HPLC analysis of the amino acids, the ${ }^{3} \mathrm{H} /{ }^{14} \mathrm{C}$ ratio was determined. The carcinogen-treated rats exhibited a significantly higher ratio than the vehicle-treated animals. This type of in vivo assay might find interesting applications in the investigation of nucleic acid alkylations as promutagenic lesions.

Since a large number of chemical carcinogens act by damaging DNA, many short-term screening tests for carcinogenicity are based upon the detection of mutational events. In the light of the recent findings that certain cellular proto-oncogenes can be activated by base substitutions (refs. in Weinberg, 1985) the search for changes in amino acid composition of proteins could become a valuable tool.

One major problem in protein variant analysis in non-clonal systems is the fact that minor changes in the relative abundance of the various amino acids in a small number of polypeptide

\footnotetext{
* Present address: Institute of Pharmacology, University of Zurich, CH-8006 Zurich, Switzerland.

** To whom correspondence should be sent.
}

chains might not be significant due to the experimental variability of the amino acid determinations. The situation becomes much more clear-cut when a particular amino acid is lacking in the wild-type polypeptide chain so that the mere presence of this amino acid provides evidence of a promutagenic lesion.

We have shown earlier with cytochrome $b_{5}$ that this approach is feasible if a low limit of detection of the wrong amino acid can be achieved with the use of radiolabel (Jauch and Lutz, 1983). The sensitivity of that system was, however, insufficient for toxicological purposes. Here, we present data on another protein, metallothionein (MT), where a polypeptide chain of 61 amino acids contains 20 cysteine (Cys) residues and lacks aromatic amino acids (Kägi and Nordberg, 1979). 
It will be shown that MT variants containing the aromatic amino acids tyrosine (Tyr) or phenylalanine (Phe) can be isolated from rat liver after administration of a mutagenic carcinogen at a dose level which would not have given rise to a significant effect in the older assay based on cytochrome $b_{5}$.

\section{Materials and methods}

\section{Animals, chemicals, and treatments}

Male rats (Iva:SIV-50.SD) were from Ivanovas, Kisslegg i. A., F.R.G. They were held 3 per macrolone cage on laboratory chow No. 343 (Klingentalmühle AG, Kaiseraugst, Switzerland) and tap water ad libitum. L- $\left[2,3-{ }^{3} \mathrm{H}\right]$ Tyrosine (Tyr; 51 $\mathrm{Ci} /$ mmole), $\mathrm{L}-\left[2,3-{ }^{3} \mathrm{H}\right]$ phenylalanine (Phe; $40 \mathrm{Ci}$ / mmole) and $\mathrm{L}-\left[\mathrm{U}-{ }^{14} \mathrm{C}\right]$ cysteine (Cys; 32.5 $\mathrm{mCi} / \mathrm{mmole}$ ) were purchased from the Radiochemical Centre, Amersham, Great Britain. $N, N$ Diethylnitrosamine (DENA; CAS registry No. 5518-5) was from Fluka AG, Buchs, Switzerland. Unlabelled amino acids were from Serva, Heidelberg, F.R.G. All other reagents were of the highest purity available from Merck, Darmstadt, F.R.G.

Three 5-week-old rats were treated for 4 weeks with $42 \mu 1$ DENA/l drinking water (corresponding to an approximate dose of $4 \mathrm{mg} / \mathrm{kg} /$ day). Food was withdrawn on the last day at $06.00 \mathrm{~h}$. At $08.00 \mathrm{~h}$, these rats received a single oral dose of 36 $\mathrm{mg} / \mathrm{kg}$ DENA in water. 3 control rats received water in the place of both subchronic and acute carcinogen treatments. At $10.00 \mathrm{~h}$ all animals were given a subcutaneous injection of $\mathrm{CdCl}_{2}$ in $10^{-4}$ $\mathrm{M} \mathrm{HCl}(1 \mathrm{mg} \mathrm{Cd} / \mathrm{rat})$ in the scapular region in order to induce MT synthesis (Andersen et al., 1978). At $14.00 \mathrm{~h}$ a liquid synthetic diet was given by gavage $(7.2 \mathrm{ml} / \mathrm{kg})$ which contained $16 \%$ sucrose plus about one third of the daily requirement of all amino acids except the aromatic amino acids tyrosine and phenylalanine. These two amino acids were supplied in tritiated form at a level of approximately $7 \mathrm{mCi} / \mathrm{kg}$ each (exact dose given in Table 1). It was thought that a dietary lack of Tyr and Phe could help to minimize the catabolism of these amino acids so that a transfer of tritium to other amino acids could be prevented as far as possible. Cys was ${ }^{14} \mathrm{C}$-marked $(11 \mu \mathrm{Ci} / \mathrm{kg})$ in order to have an internal marker for the determination of the rate of MT biosynthesis. At $20.00 \mathrm{~h}$ the animals were killed under ether anaesthesia, the livers were removed and washed in ice-cold saline.

\section{Isolation of metallothionein}

The liver was minced and homogenized with a Potter-Elvehjem-type glass-teflon device in 5 vol. $0.25 \mathrm{M}$ sucrose $10 \mathrm{mM}$ Tris- $\mathrm{HCl}$ buffer $\mathrm{pH} 8.6$ with 10 strokes at $1000 \mathrm{rpm}$. A postmicrosomal supernatant was isolated after sequential centrifugation with increasing force $(5 \mathrm{~min} 300 \times \mathrm{g} ; 5 \mathrm{~min}$ $2000 \times g ; 5 \min 10000 \times g ; 5 \mathrm{~min} 20000 \times g$ and $60 \mathrm{~min} 105000 \times g$ ). After removing the fatty layer on the top, the clear reddish supernatant was decanted and gassed for $10 \mathrm{~min}$ with $\mathrm{N}_{2}$. The solution was partially heat-denatured under nitrogen for $1 \mathrm{~min}$ at $70^{\circ} \mathrm{C}$. This procedure precipitated $60-70 \%$ of the high molecular ${ }^{3} \mathrm{H}$ activity, but should not have precipitated Cd-rich MT (Cherian, 1974). The heat-stable supernatant as well as all subsequent MT preparations were always kept under $\mathrm{N}_{2}$ atmosphere at $4^{\circ} \mathrm{C}$ between the various purification procedures. Lyophilized protein was stored at $-20^{\circ} \mathrm{C}$. The samples were lyophilized, redissolved in $4 \mathrm{ml}$ water, loaded on a Sephadex G-75-SF column $(2.5 \mathrm{~cm} \times 80 \mathrm{~cm}$; Pharmacia) and eluted with $10 \mathrm{mM}$ Tris- $\mathrm{HCl}$ buffer, $\mathrm{pH}$ 8.6. The elution of MT and of protein in general was monitored by determination of (a) $\mathrm{Zn}$ and $\mathrm{Cd}$ by atomic absorption spectrometry (Perkin-Elmer atomic absorption spectrophotometer 5000 equipped with a HGA 5000 graphite furnace), (b) ${ }^{14} \mathrm{C}$ and ${ }^{3} \mathrm{H}$ radioactivity by dual-label scintillation counting, and (c) the optical density at $280 \mathrm{~nm}$ in each fraction. MT eluted at $V_{\mathrm{c}} / V_{0}$ values between 1.6 and 2.0 as described by Chen et al. (1975). The high-molecular protein eluting at the solvent front was also collected for the determination of the average specific activity of cytosolic protein. A pool of approx. $70 \mathrm{ml}$ containing the MT was concentrated by ultrafiltration with a Diaflo YM 2 membrane (Amicon) to $10 \mathrm{ml}$, loaded on a DEAE-Sephacel column (Pharmacia; $0.9 \mathrm{~cm} \times 19 \mathrm{~cm}$ ) and eluted with a linear Tris- $\mathrm{HCl}$ gradient (10-200 mM Tris- $\mathrm{HCl}, \mathrm{pH} 8.6$, total 250 $\mathrm{ml})$. This chromatography will later be referred to as DEAE chromatography type A. It separates the two known MT isoproteins MT1 and MT2 (Shaikh and Lucis, 1971) from MT dimers and partially 
metal-depleted forms. MT peaks eluting at a Tris- $\mathrm{HCl}$ concentration below $110 \mathrm{mM}$ were pooled and lyophilized, and the Cys residues were methylcarboxylated with iodoacetic acid according to Crestfield et al. (1963) with the following modifications. The reaction was carried out under $\mathrm{N}_{2}$ atmosphere. $10 \mathrm{mg}$ each of Tyr and Phe in unlabelled form and $35 \mu 1$ 2-mercaptoethanol were added in order to keep a reaction with the labelled amino acids Tyr and Phe to a minimum. EDTA was added immediately after iodoacetic acid in order to complex the metal ions set free from the protein after the modification of the Cys residues. An additional $65 \mu 12$-mercaptoethanol was added after $4 \mathrm{~min}$ in order to trap unreacted iodoacetic acid and to stop the reaction. The mixture was dialyzed (Berghof Spectra/Por 3, cutoff mol. wt. 3500, Innovativ Labor, Adliswil, Switzerland) against 100 vol. of $10 \mathrm{mM}$ Tris- $\mathrm{HCl}, \mathrm{pH} \mathrm{8.6,}$ ultrafiltered and loaded again on DEAE-Sephacel. The column was eluted with a linear salt gradient to $400 \mathrm{mM} \mathrm{NaCl}, 50 \mathrm{mM}$ Tris- $\mathrm{HCl}, \mathrm{pH}$ 7.5 with a total of $200 \mathrm{ml}$ buffer solution (= DEAE chromatography, type B). Most of the contaminating protein eluted early and tailed only slightly into the peak of methylcarboxylated MT (MT$\left.\mathrm{CH}_{2}-\mathrm{COOH}\right)$ which eluted at about $255 \mathrm{mM}$ $\mathrm{NaCl}$. Of each MT peak, the front $15 \%$ and the tail $5 \%$ of the ${ }^{14} \mathrm{C}$ activity were discarded. The chromatography was repeated twice, whereafter the ${ }^{3} \mathrm{H} /{ }^{14} \mathrm{C}$ ratio, an indicator of the purity of the MT samples, remained constant. The last pool of pure $\mathrm{MT}-\mathrm{CH}_{2}-\mathrm{COOH}$ was dialyzed and lyophilized. 5 nmoles of both unlabelled Tyr and Phe were added as carrier and the protein was hydrolysed in $6 \mathrm{~N} \mathrm{HCl}$ for $20 \mathrm{~h}$ at $112^{\circ} \mathrm{C}$. The resulting amino acid mixture was separated by HPLC according to Hughes et al. (1982) and the fractions containing Cys- $\mathrm{CH}_{2}-\mathrm{COOH}$ (fraction No. 5), cystine (Nos. 9 and 10), Tyr (No. 12) and Phe (No. 14) were collected and counted for ${ }^{14} \mathrm{C}$ and ${ }^{3} \mathrm{H}$ radioactivity. The background count was determined from amino acid separations of mixtures of unlabelled standards. The net counts were used for the calculation of mutation indices as defined in a footnote to Table 1.

\section{Determination of specific activities}

Protein content was determined with the Folin reagent. Liquid scintillation counting was performed with samples mixed with Insta-Gel scintillation cocktail (Packard) in low background glass vials (Packard) in a Packard Tri Carb $460 \mathrm{CD}$ scintillation counter. The activity of doublelabelled samples was determined after subtraction of an adequate background activity and on the basis of a quench-indicating parameter calibrated with internally standardized samples. Vials were kept in the dark at $4^{\circ} \mathrm{C}$ for at least 1 day before being counted for up to $4 \times 30 \mathrm{~min}$.

\section{Results}

The 3 DENA-treated rats showed a slightly depressed weight gain during the 4-week pretreatment period and a reduced liver weight as compared with the controls (lines 1 and 4 of Table 1). Protein synthesis was, however, not affected by the carcinogen treatment as documented by the incorporation of labelled amino acids into protein synthesized during the 6-h lag between administration and sacrifice (lines 5 and 6). No difference was seen either in MT biosynthesis (line 7). NonMT protein collected from the front of the first Sephadex chromatography had average specific activities of $250000 \mathrm{dpm}{ }^{3} \mathrm{H}$ and $370 \mathrm{dpm}{ }^{14} \mathrm{C}$ per $\mathrm{mg}$. The high level of ${ }^{14} \mathrm{C}$ incorporation into $\mathrm{MT}$ was due to the fact that this polypeptide contains about 15 times more Cys residues than an average protein and that the rate of synthesis was higher than average because it had been stimulated by prior administration of cadmium.

The ${ }^{3} \mathrm{H} /{ }^{14} \mathrm{C}$ ratio was used to measure the MT purity. This is possible because the wild-type polypeptide contains neither Tyr nor Phe (tritium label) but 20 Cys residues $\left({ }^{14} \mathrm{C}\right.$ label) so that the ${ }^{3} \mathrm{H} /{ }^{14} \mathrm{C}$ ratio should reach a minimum upon exhaustive purification. This ratio started with a value of about 700 for high-molecular cytosolic protein and reached levels of around 0.2 for MT after the second DEAE chromatography type B. No further reduction could be achieved by an additional DEAE step. The individual purification steps served different purposes and were of various efficiency. Heat denaturation and Sephadex chromatography both resulted in an overall purification by a factor of about 2. DEAE type A chromatography was rather ineffective with respect to 
purification but was a prerequisite specifically to remove those proteins which elute in the range where carboxymethylated MT was expected to elute in a later stage. The best purification was possible after chemical modification of MT. Thanks to the exceptional abundance of Cys residues which are easily modified by carboxymethylation (thereby increasing the number of acidic groups), the first DEAE chromatography of type $B$ resulted in a reduction of the ${ }^{3} \mathrm{H} /{ }^{14} \mathrm{C}$ ratio by a factor of about 100 . The final MT- $\mathrm{CH}_{2-}$ $\mathrm{COOH}$ pool exhibited a ratio which was about 3500 times lower than that of cytosolic highmolecular weight protein. If it is assumed that the average protein contains $2 \%$ Cys and 3\% Tyr + Phe, whereas MT contains 30\% Cys, then it can be deduced that the presence of Tyr and Phe in MT must be below $0.01 \%(30: 2 \times 3: 3500)$. This

\section{TABLE 1}

INCORPORATION OF $\left[{ }^{14} \mathrm{C}\right] \mathrm{Cys},\left[{ }^{3} \mathrm{H}\right] \mathrm{Tyr}$ AND $\left[{ }^{3} \mathrm{H}\right]$ Phe INTO METALLOTHIONEIN ISOLATED FROM LIVER CYTOSOL AFTER TREATMENT OF MALE SPRAGUE-DAWLEY RATS WITH THE HEPATOCARCINOGEN DIETHYLNITROSA. MINE

\begin{tabular}{|c|c|c|c|c|c|c|}
\hline \multirow{3}{*}{$\begin{array}{l}\text { Treatment } \\
\text { Animal weight } \\
\text { at sacrifice (g) }\end{array}$} & \multicolumn{3}{|c|}{ Controls } & \multicolumn{3}{|c|}{ Diethylnitrosamine } \\
\hline & & & & & & \\
\hline & 331 & 288 & 316 & 270 & 298 & 310 \\
\hline $\begin{array}{l}{\left[{ }^{14} \mathrm{C}\right] \mathrm{Cys} \text { administered }} \\
(\mu \mathrm{Ci} / \mathrm{kg}) \\
{\left[{ }^{3} \mathrm{H}\right](\mathrm{Tyr} \text { plus Phe, } 1: 1)}\end{array}$ & 11.7 & 12.0 & 10.6 & 12.4 & 11.6 & 9.6 \\
\hline administered $(\mathrm{mCj} / \mathrm{kg})$ & 14.6 & 14.2 & 13.2 & 15.5 & 14.4 & 12.6 \\
\hline Liver weight (g) & 14.9 & 12.6 & 14.8 & 11.1 & 11.4 & 11.3 \\
\hline \multicolumn{7}{|l|}{$\begin{array}{l}\text { Amino acid incorporation } \\
\text { into cytosolic protein }\end{array}$} \\
\hline${ }^{3} \mathrm{H}$ & 19.2 & 17.8 & 18.1 & 18.0 & 17.9 & 15.2 \\
\hline${ }^{14} \mathrm{C}$ & 23.1 & 39.1 & 33.3 & 35.6 & 32.9 & 32.7 \\
\hline $\begin{array}{l}\text { into metallothionein }{ }^{b . c} \\
{ }^{14} \mathrm{C}\end{array}$ & 4031 & 3471 & 3293 & 3735 & 3078 & 3081 \\
\hline $\begin{array}{l}\text { Amount of } \mathrm{MT}-\mathrm{CH}_{2}-\mathrm{COOH} \\
\text { separated by } \mathrm{AAA}^{c} \text { (nmoles) }\end{array}$ & 29.4 & 18.1 & 16.0 & 10.5 & 35.0 & 21.5 \\
\hline $\begin{array}{l}\text { Cys- } \mathrm{CH}_{2}-\mathrm{COOH}+\text { cystine } \\
\text { in } \mathrm{AAA}\left(\mathrm{dpm}^{14} \mathrm{C}\right)\end{array}$ & 9030 & 4810 & 3630 & 3050 & 7830 & 3990 \\
\hline Tyr in AAA $\left(\mathrm{dpm}^{3} \mathrm{H}\right)$ & 55.4 & 32.2 & 24.5 & 35.9 & 62.8 & 95.7 \\
\hline Phe in AAA $\left(\mathrm{dpm}^{3} \mathrm{H}\right)$ & 113 & 60.2 & 48.6 & 56.4 & 89.6 & 96.6 \\
\hline \multicolumn{7}{|l|}{ Mutation index ${ }^{d}$} \\
\hline $\begin{array}{l}\text { For Tyr } \\
\quad \text { Mean } \pm \text { S.D. }\end{array}$ & 6.1 & $\begin{array}{l}6.7 \\
6.5 \pm 0.3\end{array}$ & 6.8 & 11.8 & $\begin{array}{l}8.0 \\
14.6 \pm 8.4\end{array}$ & 24.0 \\
\hline For Phe & 12.5 & $\begin{array}{l}12.5 \\
12.8 \pm 0.5\end{array}$ & 13.4 & 18.5 & $\begin{array}{l}11.5 \\
18.1 \pm 6.4\end{array}$ & 24.2 \\
\hline Normalized $^{e}$ & 6.4 & 6.4 & 6.8 & 9.4 & 5.9 & 12.3 \\
\hline
\end{tabular}

a Calculated from the specific activity of protein $(\mathrm{dpm} / \mu \mathrm{g})$ divided by the dose of radioactivity administered $(\mathrm{mCi} / \mathrm{kg})$.

b Determined on the basis of the pure $\mathrm{MT}-\mathrm{CH}_{2}-\mathrm{COOH}$ sample hydrolysed for the amino acid analysis (AAA).

c The amount of MT- $\mathrm{CH}_{2}-\mathrm{COOH}$ hydrolysate separated by HPLC for amino acid analysis (AAA) was determined on the basis of the methionine peak known to represent 1 amino acid residue and a molecular weight of 7442 taken as an average of the two main MT isoproteins MT1 and MT2 (Wong and Klaassen, 1979).

d $\times 10^{-3}$; Tyr index: $\left[{ }^{3} \mathrm{H}\right] \mathrm{dpm}$ Tyr $/\left[{ }^{14} \mathrm{C}\right] \mathrm{dpm} \mathrm{Cys}-\mathrm{CH}_{2}-\mathrm{COOH}+$ cystine; Phe index: $\left[{ }^{3} \mathrm{H}\right] \mathrm{dpm}$ Phe $/\left[{ }^{14} \mathrm{C}\right] \mathrm{dpm} \mathrm{Cys}-\mathrm{CH}_{2}-\mathrm{COOH}$ + cystine.

e Obtained by multiplying the individual mutation indices for Phe with the ratio of the means obtained in the control group for Tyr and Phe (example: $12.5 \times 6.5 / 12.8=6.4$; calculations have been performed with more than 2 digits). 
estimation only holds if the possibility of tritium becoming incorporated into other amino acids remains negligible. Such a tritium shift is possible, however, because of the metabolic instability of the 2,3-tritium markers in Tyr and Phe. Other amino acids can become radiolabelled, e.g., after degradative deamination of $\mathrm{Tyr}$ which produces tritiated pyridoxamine phosphate, a cofactor used for general amino transfer reactions. Although the degradation of Phe and Tyr was reduced as far as possible by administration of a liquid diet lacking these two amino acids, the process is not completely avoidable. This form of biosynthetic tritiation of MT cannot, therefore, be excluded on the basis of the radioactivity of the polypeptide. Clear results can be expected after amino acid analysis (AAA) where only that radioactivity which coelutes with the optical density of the unlabelled standards is taken to represent Tyr or Phe.

The data given in Table 1 show that at the elution times of Tyr and Phe some ${ }^{3} \mathrm{H}$ activity was detected in all 6 samples (lines 10 and 11). The combined peaks of carboxymethylated cysteine and of cystine were highly ${ }^{14} \mathrm{C}$ labelled and served as a quantitative indicator for the MT synthesis of each individual animal. The ratio of these values (division by the values in line 9) was named mutation index in Table 1 and represents the extent of incorporation of Tyr and Phe into MT synthesized during that period of time when radiolabelled amino acids were available. The individual values for the 3 control animals revealed very small variability for both indices Tyr and Phe, whereas the carcinogen-treated animals, firstly, yielded higher indices (except for one Phe value which was at control level) and, secondly, exhibited significantly larger variability within the groups ( $F$ test). Comparison of the combined Tyr plus Phe data for treated vs. control animals with the Wilcoxon rank sum test revealed a level of significance of $p<0.05$, showing that the carcinogen treatment resulted in a significantly increased incorporation of "wrong" amino acids.

The fact that the Tyr and Phe peaks collected from the amino acid analysis of the control rats were also radiolabelled to a minor extent raises the question about the specificity of the mutation assay presented. Either the MT samples used for the amino acid analysis were still contaminated with non-MT protein or it must be concluded that the control animals did not have an error-free protein synthesis. Miscodings might for instance have been induced by the administration of $\mathrm{Cd}$ which was given to all animals in order to stimulate MT synthesis. A mutagenic activity of $\mathrm{Cd}$ had been reported in a number of systems, some of which detect base pair substitutions (refs. in Ochi et al., 1984). Both modes of contamination cannot, however, explain the difference between the two groups so that the DENA treatment must have been responsible for the effect.

\section{Discussion}

We have shown that the treatment of rats with an ethylating carcinogen can result in detectable changes in the amino acid composition of a protein. Prerequisite is a well characterized protein lacking one or more amino acids in the wild type. The present assay, based on testing such changes in metallothionein, is more sensitive than the one with cytochrome $b_{5}$ described previously (Jauch and Lutz, 1983) because of the following advantages: Firstly, the rate of MT synthesis can be stimulated by administration of metal ions, particularly cadmium. The induced rate of synthesis can reach values of 2-3 nmoles $/ \mathrm{h} / \mathrm{g}$ liver (Andersen et al., 1978), i.e., 20-30 times higher than the rate of cytochrome $b_{5}$ synthesis and at least 10 times higher than for the average cytosolic liver protein. It should be mentioned here that it is not the total amount of a specific protein chain in the cell which is important for the limit of detection of variants in this type of assay but the rate of synthesis during that time period when the radiolabelled "wrong" amino acids are available for incorporation. Secondly, both Tyr and Phe are coded for by triplets which have 2 bases in common with triplets coding for Ser or Cys. Since the latter amino acids represent about $50 \%$ of all residues in MT, the probability of a detectable amino acid substitution becomes relatively high.

A complete analysis of all theoretically possible steps which lead to incorporation of Tyr or Phe into MT has been compiled elsewhere (Jauch, 1984). Suffice to say here that the most important contribution for Tyr expression comes from an ethylation of guanine in mRNA in the UGC and 
UGU triplets coding for Cys. Miscoding of $O^{6}$ ethylguanine in RNA with uracil instead of cytosine in TRNA would lead to the incorporation of Tyr into the polypeptide chain. After a single dose of $36 \mathrm{mg}$ DENA $/ \mathrm{kg}$ body weight, there will be about one $O^{6}$-ethylguanine per $10^{5} \mathrm{DNA}$ guanines, at a time between 6 and $12 \mathrm{~h}$ after oral administration (Scherer et al., 1977). A similar level of RNA damage can be expected (Lutz, 1979). A maximum rate of variant $\mathrm{Tyr}$ incorporation of $20 / 2 \times 10^{-5}=10^{-4}$ can be calculated from the two triplets coding for 20 Cys residues in MT. This means that about one out of $10^{4}$ newly synthesized MT chains would have one Tyr incorporated. With similar estimates for the remaining possibilities for erroneous transcription and translation (Jauch, 1984), a total theoretical probability for a Tyr is about one in $3000 \mathrm{MT}$ molecules. This Tyr frequency is alone about 10 times higher than could be expected by a similar estimate with the cytochrome $b_{5}$-methionine assay.

The experimental frequency reported here is astonishingly close: The average net mutation index for Tyr was $0.0146-0.0065=0.0081 \mathrm{dpm}$ Tyr/dpm Cys. Taken that about 622 times more radiolabel was administered in the form of $\mathrm{Tyr}$ as compared with Cys, and knowing that MT contains 20 Cys residues, the frequency of Tyr can be calculated to be $0.0081 \times 20: 622=2.6 \times 10^{-4}$. This means that one out of 3800 MT chains contained a DENA treatment-related Tyr.

A similar estimate for Phe shows that the most important contribution comes from DNA-guanine ethylations in AGA and AGG triplets coding for Ser. It was not attempted in this case to compare theoretical and experimental mutation frequencies because it was considered impossible to estimate the mutational consequences on the DNA level of the chronic administration of DENA in the drinking water.

The quantitative comparison of theoretical and experimental results for Tyr as described above can only be regarded as a first attempt. Overestimations must result from the assumption that the $O^{6}$-ethylated guanine miscodes $100 \%$ with the base coding for the wrong amino acid. It has also been assumed that the specific activities of Tyr, Phe and Cys incorporated into protein are proportional to the administered radioactivities.
Our results demonstrate that the potency of genotoxic carcinogens to induce premutational lesions can, in principle, be determined in vivo. Both assays, the one based on cytochrome $b_{5}$ reported previously and the one based on metallothionein described here, could also reveal organ specificities of carcinogens because both proteins are widely distributed in several tissues (Onosaka and Cherian, 1981, for MT). The present assay is markedly more sensitive. Additional improvements could be obtained by modifications of the protein purification method for higher yield, higher purity, and faster isolation. This could increase the applicability of the assay as a tool in genetic toxicology testing but much work remains to be done in order to discriminate between the effects of single versus repeated administrations and to distinguish between the contributions of RNA alkylations, DNA alkylations, and mutations.

\section{Acknowledgements}

We thank Drs. J. Kägi and M. Vasák (Institute of Biochemistry, University of Zurich) for valuable advice on metallothionein and Dr. R. Fischer and Ms. S. Huber (Institute of Biochemistry, Swiss Federal Institute of Technology Zurich) for their help with the amino acid analyses.

\section{References}

Andersen, R.D., W.P. Winter, J.J. Maher and I.A. Bernstein (1978) Turnover of metallothioneins in rat liver, Biochem. J., 174, 327-338.

Chen, R.W., P.D. Whanger and P.H. Weswig (1975) Biological function of metallothionein, I. Synthesis and degradation of rat liver metallothionein, Biochem. Med., 12, 95-105.

Cherian, M.G. (1974) Isolation and purification of cadmium binding proteins from rat liver, Biochem. Biophys. Res. Commun., 61, 920-926.

Crestfield, A.M., S. Moore and W.H. Stein (1963) The preparation of reduced and $S$-carboxymethylated proteins, J. Biol. Chem., 238, 622-627.

Hughes, G.J., K.H. Winterhalter, E. Boller and K.J. Wilson (1982) Amino acid analysis using standard high-performance liquid chromatographic equipment, J. Chromatogr., 235, 417-426.

Jauch, A. (1984) Entwicklung emes somatischen Mutationsassays beim Săuger an zwei ausgewählten Loci: Isolation von Mutagen-induzierten Proteinvarianten des Cytochrom $b_{5}$ und des Metallothioneins, Diss. ETH No. 7432 (Ph.D. thesis), ADAG, Zürich. 
Jauch, A., and W.K. Lutz (1983) In vivo assay for somatic point mutations induced by genotoxic carcinogens: incorporation of $\left[{ }^{35} S\right]$ methionine into a rat liver cytochrome $b_{5}$ normally lacking sulphur-containing amino acids, Chem.Biol. Interact., 46, 139-149.

Kagi, J.H.R., and M. Nordberg (Eds.) (1979) Metallothionein, Birkhăuser, Basel.

Lutz, W.K. (1979) In vivo covalent binding of organic chemicals to DNA as a quantitative indicator in the process of chemical carcinogenesis, Mutation Res., 65, 289-356.

Ochi, T., M. Mogi, M. Watanabe and M. Obsawa (1984) Induction of chromosomal aberrations in cultured Chinese hamster cells by short-term treatment with cadmium chloride, Mutation Res., 137, 103-109.

Onosaka, S., and G. Cherian (1981) The induced synthesis of metallothionein in various tissues of rat in response to metals, I. Effect of repeated injection of cadmium salts, Toxicology, 22, 91-101.

Scherer, E., A.P. Stewart and P. Emmelot (1977) Kinetics of formation of $O^{6}$-ethylguanine and its removal from liver DNA of rats receiving diethylnitrosamine, Chem.-Biol. Interact., 19, 1-11.

Shaikh, Z.A., and O.J. Lucis (1971) Isolation of cadmium-binding proteins, Experientia, 27, 1024-1025.

Weinberg, R.A. (1985) The action of oncogenes in the cytoplasm and nucleus, Science, 230, 770-776.

Wong, K., and C.D. Klaassen (1979) Isolation and characterization of metallothionein which is highly concentrated in newborn rat liver, J. Biol. Chem., 254, 12399-12403. 